\title{
Trust As A Missing Link Between Quality of Work Life And Subjective Well-Being
}

La confianza como un eslabón perdido entre calidad de vida laboral y bienestar subjetivo

Confiar como um link ausente entre qualidade de vida profissional e bem-estar subjetivo

\section{Shivani Agarwal ${ }^{1}$}

Received: September $16^{\text {th }}, 2019$

Accepted: November 25 th, 2019

Available: January $31^{\text {th }}, 2020$

How to cite this article:

S. Agarwal, "Trust as A Missing Link Between Quality of Work Life and Subjective

Well-Being," Revista Ingeniería Solidaria, vol. 16, no. 1, 2020. doi: https://doi.org/10.16925/2357-6014.2020.01.06

Artículo de investigación. https://doi.org/10.16925/2357-6014.2020.01.06

1 KIET Group of Institutions, Delhi-NCR, Ghaziabad ORCID: https://orcid.org/0000-0002-3205-552X

E-mail: shivani.agarwal@kiet.edu 


\section{Abstract}

Introduction:The research paper "Trust as a missing link between Quality of work life and Subjective well-being", was developed at KIET School of Management, KIET Group of Institutions in the year 2019.

Problem: Organizations have initiated the search for intervening strategies whenproviding primed quality of work life to retain potential employees for heightened productivity, efficiency, effectiveness and performance.

Objective: The main aim of thisstudy is to examine the influence of quality of work life on subjective well-being of employees. Furthermore, the present study also explores the aforementionedassociation with the mediating effect of trust.

Methodology: The study is comprised of 350 managers working in IT industries. The participants were a convenient purposive sample. The data wasanalyzed by a number of statistical techniques such as: Pearson's Product Moment Method and Stepwise Multiple Regression Analysis, which were used to explore the influence of quality of work life on trust and subjective well-being.

Conclusion: This study makes a theoretical contribution in understanding trust as a missing link between QWL and subjective well-being.

Originality: The most important aspect which binds an employee to the organization is the level of trust and the well-being of employees at the workplace. This perspective has currently been neglected by the management practitioners and it can be stated that low levels of trust and well-being, when overflowing into the other domains of life,lead to further distrust and life dissatisfaction and makes an employee less productive and incompetent when confrontinglife challenges.

Restrictions: The research paper is entirely relianton cross-sectional data that could also be extended while selecting larger multicultural samples for the better understanding and measurement of cognitive processes across organizational cultures.

Keywords: Subjective well-being, Trust,Quality of work life.

\section{Resumen}

Introducción: el trabajo de investigación “La confianza como un eslabón perdido entre la calidad de vida laboral y el bienestar subjetivo", fue desarrollado en KIET School of Management, KIET Group of Institutions en el año 2019.

Problema: las organizaciones han iniciado la búsqueda de estrategias de intervención al proporcionar una calidad de vida laboral para retener a los empleados potenciales para una mayor productividad, eficiencia, efectividad y rendimiento.

Objetivo: el objetivo principal de este estudio es examinar la influencia de la calidad de la vida laboral en el bienestar subjetivo de los empleados. Además, el presente estudio también explora la asociación mencionada anteriormente con la mediación efecto de la confianza.

Metodología: El estudio está compuesto por 350 gerentes que trabajan en industrias de TI. Los participantes fueron convenientes, muestra intencional. Los datos se analizaron mediante una serie de técnicas estadísticas como: Método momento Pearson del producto y análisis de regresión múltiple por pasos, que se utilizaron para explorar la influencia de calidad de vida laboral en confianza y bienestar subjetivo.

Conclusión: este estudio hace una contribución teórica en la comprensión de la confianza como un eslabón perdido entre QWL y bienestar subjetivo.

Originalidad: el aspecto más importante que une a un empleado a la organización es el nivel de confianza y el bienestar de los empleados en el lugar de trabajo. Esta perspectiva ha sido descuidada actualmente por la 
gerencia profesionales y se puede afirmar que hay bajos niveles de confianza y bienestar, cuando se desbordan en el otro dominios de la vida, conducen a una mayor desconfianza e insatisfacción de la vida y hace que un empleado sea menos productivo y competente al enfrentar desafíos de la vida.

Restricciones: El trabajo de investigación es completamente dependiente de datos de sección transversal que también podrían extenderse a muestras multiculturales más grandes para una mejor comprensión y medición de los procesos cognitivos. a través de culturas organizacionales.

Palabras clave: bienestar subjetivo, confianza, calidad de vida laboral.

\section{Resumo}

Introdução: o trabalho de pesquisa "Confiança como elo perdido entre a qualidade de vida no trabalho e o bem-estar subjetivo", Foi desenvolvido na KIET School of Management, KIET Group of Institutions em 2019.

Problema: as organizações começaram a busca de estratégias de intervenção, fornecendo uma qualidade de vida útil para reter funcionários em potencial para maior produtividade, eficiência, eficácia e desempenho.

Objetivo: o principal objetivo deste estudo é examinar a influência da qualidade de vida no trabalho no bem-estar subjetivo de funcionários. Além disso, o presente estudo também explora a associação mencionada com mediação. efeito de confiança.

Metodologia: 0 estudo é composto por 350 gerentes que trabalham nas indústrias de TI. Os participantes foram convenientes, exibição intencional Os dados foram analisados usando uma série de técnicas estatísticas, tais como: método do momento de Pearson do produto e análise de regressão múltipla stepwise, que foram usadas para explorar a influência qualidade de vida no trabalho com confiança e bem-estar subjetivo.

Conclusão: este estudo faz uma contribuição teórica na compreensão da confiança como elo perdido entre a QVT e bem-estar subjetivo.

Originalidade: o aspecto mais importante que une um funcionário à organização é o nível de confiança e o bem-estar dos funcionários no local de trabalho. Essa perspectiva foi atualmente negligenciada pela administração profissionais e pode-se dizer que existem baixos níveis de confiança e bem-estar, quando transbordam no outro domínios da vida, levam a uma maior desconfiança e insatisfação da vida e tornam um funcionário menos produtivo e competente ao enfrentar os desafios da vida.

Restrições: 0 trabalho de pesquisa é completamente dependente de dados transversais que também podem ser estendidos a amostras multiculturais maiores para uma melhor compreensão e medição dos processos cognitivos. através das culturas organizacionais.

Palavras-chave: bem-estar subjetivo, confiança, qualidade de vida no trabalho.

\section{Introduction}

Today, amidst the 'war for talent', it is quintessential for a well-functioning organization to capture the hearts and minds of employees in order to maintain an adequate and qualified workforce. Towards this end, a high quality of work life (commonly abbreviated as QWL) is what organizations aspire for and which is further considered as a win-win situation for all working in the organization[1],[2], [3]. The term QWL was first introduced after performing an experiment within an organization for the first time, 
developed by General Motors in the late 1960s. The concept of QWL also draws from the 'open socio-technical system' which arrived in the 1970s,providing autonomy at the workplace, interdependence, and self-involvement with the initiative of "best fit" among technology and societal organization.

Another variable which has been a part of this study is trust, an attitudinal outcome. Trust is the belief that one person will not deliberately or knowingly harm another person but will look after the interests of the other [4]. Trust can be further divided asa cognitive evaluation of performance (rational) or based on affective response (emotional). In this paper, the prime focus is on interpersonal trust within the organizations. Research on trust mainly focuses on conflict resolution, citizenship behavior, job satisfaction, a supervisor's and subordinate's support and strategic collaboration and cooperation. But still there is a dearth of research from the perspective of up to what extent quality of work life leads to trust (positive attitudinal behavior at the workplace) of IT employees and generates confidence within them so that the employees are competent enough to be resilient to adversities, which can further be contributed to positive and optimistic personality. Furthermore, the most prominent challenge for organizations is talent acquisition and retentionwhilst the most challenging work for employees is to have fun at their job in the IT industry and also to encourage the well-being of employees at the workplace, that is, "subjective well-being (written as SWB)".

The extent to which quality of work life contributes to the perception of trust and SWB of employees working in IT industries is not wellknown. There is a dire need of researchthatconsiders IT employees just as human beings. Their attitudinal and behavioral outcome through workplace must be the major concern while transcending them as true human beings. This would direct IT organizations' efforts to enhance life, not only in the workplace but also at non-work domains, and help employees perceive their life as fully engaging and meaningful. Therefore, the main aimof this present study is to analyze the level of trust as a missing link between quality of work life and subjective well-being.

1.1 Concept of Quality of Work Life (QWL): Using the framework of QWL, the term "QWL is the favorableness or unfavorableness of a total job environment and working conditions that are excellent for people as well as for the economic health of the organization"[5]. McDonald defined that there are seven factors [6] which comprise QWL in an organization which are as follows: 
a) Support from Manager or Supervisor (SMS): This dimension refers to the extent to which the manager or supervisor is seen to deal fairly with all employees, and whether he or she is seen to be open to new ways of working.

b) Freedom from Work-related Stress (FWS): It denotes the degree up to which employees feel their workload is justifiable.

c) Salary and Additional Benefits (SAB): This dimension denotes the adequacy of salary in comparison to the work assigned with respect to their qualification, work experience and responsibilities at workplace. It also includes the adequacy of any additional benefits employees receive.

d) Job Satisfaction, Challenge, Use of Skills, and Autonomy (JSCA): This dimension focuses on whether employees feel happy and enjoy the work which is assigned in their jobs. The extent to which work allows employees to do what they feel they are best at and is perceived as being challenging, stimulating and offering a variety of tasks to be performed.

e) Relationships with Work Colleagues (RWC): In this dimension, emphasis is given to the degree to which employees feel that they have harmonious relationships with their colleagues.

f) Involvement and Responsibility at Work (IRW): It reflects the degree to which employees feel more engrossed intheir own work and contribute to decision making at work.

g) Communication, Decision-making, and Job Security(CDJS): It indicates the level to which communication within the organization is perceived as being good, and employees feel properly informed about the work of the organization as a whole and its broader goals.

1.2 Concept of Trust: Trust is the key concept in sociology and psychology for knowing about human beings and social systems. Trust can be defined as "a psychological state comprising a willingness to accept vulnerability based on positive expectations of the intentions or behavior of another"[7]. The current study has adopted the concept of trust which has been propounded by Daniel J. McAllister and defined the term trust as, "the extent to which a person is confident in and willing to act on the basis of, the words, actions and decisions, of another"[8]. According to McAllister, trust constitutes two dimensions:

a) Cognition-based trust (CBT): It is the extent of willingness/confidence that exists in theother party's reliability and competence.This factor is rational in nature which is further used for trusting the other party. 
b) Affect-based trust (ABT): This dimension of trust is defined as subjective in nature, as the perceived trustworthiness of one is based on the emotions, moods and feelings of the other party.

1.3 Concept of Subjective Well-Being (SWB): Ed Diener coined the term SWB and conceptualized as to 'how people evaluate their lives'. According to Diener (1984), SWB comprises two components (a) cognitive component (life satisfaction) and (b) affective component (emotional well-being)[9]. In this research, a tripartite model of subjective well-beingexists in which three interrelated yet distinct factors were used: Positive Affect, Negative Affect and Life Satisfaction.

a) Life Satisfaction ( $L S$ ): It is a conscious cognitive judgment of one's verve at a particular point in time ranging from negative to positive or vice versa.

b) Positive Affect (PA): The pleasurable feeling which shows the degree to which a person feels happy, excited, proud and determined.

c) Negative Affect (NA): Negative affect or painful feeling which shows the degree to which a person feels upset, scared orirritable.

On the basis of the above discussion, thepresent study aims to analyze the construct 'trust' as a missing link between the associations of quality of work life and subjective well-being of employees. It has been hypothesized that the positive work experiences (perception of quality of work life) will influencethe generation of trust among members whilstemployees would also experience subjective well-being. As a result, IT employees perceive their lives as more meaningful with a sense of happiness, activeness, absence of stress andfeelingaccepted while having harmonious relationships within the family and other domains of life. Thus, we hypothesise:

H1: Quality of work life will influence trust.

H2: Quality of work life will influence Subjective well-being.

H3: Trust will mediate the association among Quality of work life and Subjective well-being.

\section{Methodology}

2.1 Procedure and Sample: The samples for this study were collected through convenience sampling and consist of 350 employees working in the IT industry. The sample is comprised of managers, working in IT industries. Of the 350 sample, the majority 
proportion (70\%) was male, while 30\% were female. The participants were also further informed about maintaining the privacy of responses.

2.2 Instruments and Scoring: The data for the study was gathered and measured by three scales. The description of each scale has been given as follows:

a) Personal Information Sheet: The personal information sheet included a list of questions such as: Name of the employee, Designation,Age, Marital Status, Gender, Educational Qualification, Work Experience and Organization's Name.

b) Quality of Work Life Scale (QWLS): QWL has been measured by a QWLS scale which was developed by Angus S. McDonald [6] and consists of 7 dimensions and 53 items. Participants responded on a five-point Likertscale ranging from $1=$ strongly agree to $5=$ strongly disagree. The reliability of the scale was reported as 0.94 .

c) Trust: Trust was measured by Daniel J. McAllister [8] scale which consists of 11 items and 2 dimensions. The items in the scale are measured on a 7-point format, ranging from 1= Strongly Disagree to 7=Strongly Agree. One total score of trust has been reported, while scores for the two dimensions of trust were also obtained. The Cronbach alpha for the affect-based trust was 0.89 and cognition-basedtrust was 0.91 respectively, which is relatively high.

d) Subjective Well-Being Scale (SWBS): For measuring well-being of employees within organizations, two scales were used.These identified the three dimensions of Subjective Well-Being such as: Life satisfaction, Positive Affect, and Negative Affect.

- Life satisfaction: The Satisfaction with Life Scale (SWLS) which was developed by Diener, Emmons, Larsen \& Griffin (1985) was used to measured life satisfaction, which consists of 5 items and the scale ranges from $1=$ Strongly Disagree to $7=$ Strongly Agree. The reliability co-efficient of the scale is 0.87 .

- Positive Affect and Negative Affect: Positive Affect and Negative Affect Scale (PANAS) developed by Watson, Clark \& Tellegen [10] was used to measure 20 items of affective dimension. PANAS is a five-point Likert scale and the responses ranged from (1) Very slightly or Not at All to Extremely (5). The Cronbach alpha for the positive affect was 0.84 and negative affect was 0.90 respectively, which is relatively high. 
2.3 Statistical Analysis: The collected data wasput into the software (SPSS) for applying the technique (Stepwise Multiple Regression Analysis), to analyze the effect of trust as a missing link between QWL and SWB. In addition, EFA was implied to study the factor structure of the variables taken in the study. Furthermore, the bootstrapping approach using SEM was employed to study QWL as independent and SWB as dependent variables respectively, whereas the third construct, trust, acted as a mediator variable. The analysis was completed using SPSS ${ }^{\circledR} 17$ for Principal Component Analysis, Pearson correlation and Stepwise Regression Analysis and AMOS ${ }^{\circledR} 20$ was employed for mediation effect.

2.4 The KMO and Bartlett's Test: The KMO measure of the QWL scale was found to be 0.871 and the Bartlett test, $\chi^{2}$ value was found to be $(1378)=16532.96$ with $p<$ 0.001. For the Trust scale, KMO was measuredas 0.922 and the Bartlett test $\chi^{2}$ value was found to be $(55)=2789.55$ with $p<0.001$. Lastly, for SWB, KMO was measured as 0.734 and the Bartlett test $\chi^{2}$ value was found to be $(300)=4661.62$ with $p<0.001$.

2.5 Factor Structures of the Measures: To study the scales of QWL, Trust and SWB, Principal Component Analysis (PCA) with Kaiser's Varimax Rotation Method was used. The QWL scale was subjected to factor analysis on the basis of Exploratory Factor Analysis, and seven factors were found with eigenvalues greater than 1.00 which are represented in Table 1. The seven factors reported for 66.75 percent of the total variance. The items which havemore than 0.50 factor loading will be further used for analysis. The communalities ranged from 0.27 to 0.86 but factor analysis of $\mathrm{QWL}$ scale and its factors have shown that 44 items were extracted out of the 53 items for further analysis.

Table 1. Items marked with * have factor loadings less than 0.50 and are excluded from the scale.

\begin{tabular}{|c|c|c|c|c|c|c|c|c|}
\hline \multirow{2}{*}{ Items } & \multicolumn{7}{|c|}{ Component } & \multirow{2}{*}{$h^{2}$} \\
\hline & 1 & 2 & 3 & 4 & 5 & 6 & 7 & \\
\hline Support frommanager 1 & & & 0.58 & & & & & 0.59 \\
\hline Support frommanager 2 & & & & 0.72 & & & & 0.75 \\
\hline Support frommanager 3 & & $0.41^{*}$ & & & & & & 0.53 \\
\hline Support frommanager 4 & & & 0.62 & & & & & 0.64 \\
\hline Support frommanager 5 & $0.46^{*}$ & & & & & & & 0.66 \\
\hline Support frommanager 6 & & & & 0.65 & & & & 0.81 \\
\hline
\end{tabular}


(viene)

\begin{tabular}{|c|c|c|c|c|c|c|c|c|}
\hline \multirow{2}{*}{ Items } & \multicolumn{7}{|c|}{ Component } & \multirow{2}{*}{$\mathbf{h}^{2}$} \\
\hline & 1 & 2 & 3 & 4 & 5 & 6 & 7 & \\
\hline Support frommanager 7 & 0.67 & & & & & & & 0.62 \\
\hline Support frommanager 8 & & 0.65 & & & & & & 0.65 \\
\hline Support frommanager 9 & & & 0.68 & & & & & 0.82 \\
\hline Support frommanager 10 & & 0.68 & & & & & & 0.71 \\
\hline Freedom from work related stress 1 & 0.60 & & & & & & & 0.66 \\
\hline Freedom from work related stress 2 & & & & & $0.48^{*}$ & & & 0.53 \\
\hline Freedom from work related stress 3 & & & & & & 0.62 & & 0.77 \\
\hline Freedom from work related stress 4 & 0.70 & & & & & & & 0.64 \\
\hline Freedom from work related stress 5 & 0.66 & & & & & & & 0.64 \\
\hline Freedom from work related stress 6 & & & 0.78 & & & & & 0.72 \\
\hline Freedom from work related stress 7 & & & & & 0.75 & & & 0.62 \\
\hline Freedom from work related stress 8 & 0.62 & & & & & & & 0.47 \\
\hline Salary and additional benefits 1 & $0.32^{*}$ & & & & & & & 0.72 \\
\hline Salary and additional benefits 2 & & 0.78 & & & & & & 0.79 \\
\hline Salary and additional benefits 3 & & 0.74 & & & & & & 0.77 \\
\hline Salary and additional benefits 4 & & & & & 0.87 & & & 0.78 \\
\hline Salary and additional benefits 5 & & 0.74 & & & & & & 0.79 \\
\hline Relationship with work colleagues 1 & 0.68 & & & & & & & 0.55 \\
\hline Relationship with work colleagues 2 & & & 0.63 & & & & & 0.61 \\
\hline Relationship with work colleagues 3 & & & & & & 0.57 & & 0.81 \\
\hline Relationship with work colleagues 4 & & & & $0.32^{*}$ & & & & 0.55 \\
\hline Relationship with work colleagues 5 & $0.40^{*}$ & & & & & & & 0.65 \\
\hline Involvement and responsibility at work 1 & & & 0.58 & & & & & 0.50 \\
\hline Involvement and responsibility at work 2 & & & 0.71 & & & & & 0.61 \\
\hline Involvement and responsibility at work 3 & & & & 0.88 & & & & 0.86 \\
\hline $\begin{array}{l}\text { Communication, decision-making and job } \\
\text { security } 1\end{array}$ & & 0.50 & & & & & & 0.59 \\
\hline $\begin{array}{l}\text { Communication, decision-making and job } \\
\text { security } 2\end{array}$ & & & & & & 0.55 & & 0.60 \\
\hline $\begin{array}{l}\text { Communication, decision-making and job } \\
\text { security } 3\end{array}$ & & & & & & & 0.79 & 0.68 \\
\hline $\begin{array}{l}\text { Communication, decision-making and job } \\
\text { security } 4\end{array}$ & 0.61 & & & & & & & 0.63 \\
\hline $\begin{array}{l}\text { Communication, decision-making and job } \\
\text { security } 5\end{array}$ & & & & 0.73 & & & & 0.84 \\
\hline $\begin{array}{l}\text { Communication, decision-making and job } \\
\text { security } 6\end{array}$ & & & & 0.91 & & & & 0.84 \\
\hline $\begin{array}{l}\text { Communication, decision-making and job } \\
\text { security } 7\end{array}$ & 0.53 & & & & & & & 0.69 \\
\hline $\begin{array}{l}\text { Communication, decision-making and job } \\
\text { security } 8\end{array}$ & & 0.70 & & & & & & 0.70 \\
\hline
\end{tabular}

(continúa) 
(viene)

\begin{tabular}{|c|c|c|c|c|c|c|c|c|}
\hline \multirow{2}{*}{ Items } & \multicolumn{7}{|c|}{ Component } & \multirow{2}{*}{$h^{2}$} \\
\hline & 1 & 2 & 3 & 4 & 5 & 6 & 7 & \\
\hline $\begin{array}{l}\text { Communication, decision-making and job } \\
\text { security } 9\end{array}$ & & $0.32^{*}$ & & & & & & 0.27 \\
\hline $\begin{array}{l}\text { Communication, decision-making and job } \\
\text { security } 10\end{array}$ & 0.57 & & & & & & & 0.59 \\
\hline $\begin{array}{l}\text { Job satisfaction, challenge, use of skills and } \\
\text { autonomy } 1\end{array}$ & & & & & $0.49^{*}$ & & & 0.60 \\
\hline $\begin{array}{l}\text { Job satisfaction, challenge, use of skills and } \\
\text { autonomy } 2\end{array}$ & 0.59 & & & & & & & 0.69 \\
\hline $\begin{array}{l}\text { Job satisfaction, challenge, use of skills and } \\
\text { autonomy } 3\end{array}$ & 0.51 & & & & & & & 0.63 \\
\hline $\begin{array}{l}\text { Job satisfaction, challenge, use of skills and } \\
\text { autonomy } 4\end{array}$ & & 0.55 & & & & & & 0.56 \\
\hline $\begin{array}{l}\text { Job satisfaction, challenge, use of skills and } \\
\text { autonomy } 5\end{array}$ & & & & & & 0.80 & & 0.79 \\
\hline $\begin{array}{l}\text { Job satisfaction, challenge, use of skills and } \\
\text { autonomy } 6\end{array}$ & 0.63 & & & & & & & 0.67 \\
\hline $\begin{array}{l}\text { Job satisfaction, challenge, use of skills and } \\
\text { autonomy } 7\end{array}$ & & 0.65 & & & & & & 0.64 \\
\hline $\begin{array}{l}\text { Job satisfaction, challenge, use of skills and } \\
\text { autonomy } 8\end{array}$ & & & & & & 0.55 & & 0.66 \\
\hline $\begin{array}{l}\text { Job satisfaction, challenge, use of skills and } \\
\text { autonomy } 9\end{array}$ & & & & & & $0.47^{*}$ & & 0.77 \\
\hline $\begin{array}{l}\text { Job satisfaction, challenge, use of skills and } \\
\text { autonomy } 10\end{array}$ & 0.53 & & & & & & & 0.72 \\
\hline $\begin{array}{l}\text { Job satisfaction, challenge, use of skills and } \\
\text { autonomy } 11\end{array}$ & & 0.59 & & & & & & 0.67 \\
\hline $\begin{array}{l}\text { Job satisfaction, challenge, use of skills and } \\
\text { autonomy } 12\end{array}$ & & & & 0.65 & & & & 0.76 \\
\hline Eigen values & 7.92 & 7.40 & 5.04 & 4.81 & 3.87 & 3.51 & 2.74 & \\
\hline$\%$ of Variance & 14.95 & 13.97 & 9.51 & 9.19 & 7.31 & 6.63 & 5.175 & 66.75 \\
\hline
\end{tabular}

Source: own work

For factor analysis of the Trust Scale shown in Table 2, the same procedure was applied, while considering the two dimensions of trust which accounted for 69.48 of variance. Two factors were analyzed and a total of 11 items. 10 items were extracted for further analysis as they had a factor loading of greater than0.50. The communalities ranged from 0.57 to 0.86 . 
Table 2. Items marked with * have factor loadings less than 0.50 and are excluded from the scale.

\begin{tabular}{lccc}
\hline \multirow{2}{*}{ Variables/Items } & $\mathbf{1}$ & $\mathbf{2}$ & $\mathbf{h}$ \\
\cline { 2 - 3 } & 0.75 & & 0.57 \\
\hline Affect-based Trust 1 & 0.82 & 0.68 \\
\hline Affect-based Trust 2 & 0.62 & 0.57 \\
\hline Affect-based Trust 3 & 0.83 & 0.70 \\
\hline Affect-based Trust 4 & 0.75 & 0.65 \\
\hline Affect-based Trust 5 & 0.87 & 0.75 \\
\hline Cognition-based trust 1 & 0.86 & 0.73 \\
\hline Cognition-based trust 2 & 0.78 & 0.63 \\
\hline Cognition-based trust 3 & 0.88 & 0.78 \\
\hline Cognition-based trust 4 & 0.85 & 0.72 \\
\hline Cognition-based trust 5 & $0.04^{*}$ & 0.86 \\
\hline Cognition-based trust 6 & 6.46 & 1.18 \\
\hline Eigenvalues & 58.71 & 10.76 \\
\hline \% of Variance & & 69.48 \\
\hline
\end{tabular}

Source: own work

In Table 3 the same procedure was applies for SWB through Principal Component Analysis, which extracted 20 items from 25 items. The communalities ranged from 0.20 to 0.71 . The dimensions of SWB accounted for 47.91 percent of variance.

Table 3. Items marked with * have factor loadings less than 0.50 and are excluded from the scale.

\begin{tabular}{|c|c|c|c|c|}
\hline \multirow{2}{*}{ Items } & \multicolumn{3}{|c|}{ Component } & \multirow{2}{*}{$\mathbf{h}^{2}$} \\
\hline & 1 & 2 & 3 & \\
\hline Life Satisfaction1 & & & 0.71 & 0.66 \\
\hline Life Satisfaction2 & & & 0.80 & 0.71 \\
\hline Life Satisfaction 3 & & & 0.61 & 0.41 \\
\hline Life Satisfaction4 & & & 0.64 & 0.45 \\
\hline Life Satisfaction5 & & & $0.46^{*}$ & 0.24 \\
\hline Positive Affect 1 & 0.72 & & & 0.56 \\
\hline Positive Affect 2 & & & $0.46^{\star}$ & 0.37 \\
\hline Positive Affect 3 & $0.48^{*}$ & & & 0.48 \\
\hline Positive Affect 4 & 0.76 & & & 0.64 \\
\hline Positive Affect 5 & 0.81 & & & 0.68 \\
\hline
\end{tabular}


(viene)

\begin{tabular}{|c|c|c|c|c|}
\hline \multirow{2}{*}{ Items } & \multicolumn{3}{|c|}{ Component } & \multirow{2}{*}{$h^{2}$} \\
\hline & 1 & 2 & 3 & \\
\hline Positive Affect 6 & 0.71 & & & 0.55 \\
\hline Positive Affect 7 & 0.82 & & & 0.68 \\
\hline Positive Affect 8 & 0.61 & & & 0.38 \\
\hline Positive Affect 9 & 0.69 & & & 0.59 \\
\hline Positive Affect 10 & 0.55 & & & 0.33 \\
\hline Negative Affect 1 & & 0.53 & & 0.30 \\
\hline Negative Affect 2 & & 0.69 & & 0.54 \\
\hline Negative Affect 3 & & 0.51 & & 0.50 \\
\hline Negative Affect 4 & & $0.35^{\star}$ & & 0.20 \\
\hline Negative Affect 5 & & 0.71 & & 0.53 \\
\hline Negative Affect 6 & & 0.76 & & 0.58 \\
\hline Negative Affect 7 & & 0.51 & & 0.27 \\
\hline Negative Affect 8 & & 0.60 & & 0.36 \\
\hline Negative Affect 9 & & 0.52 & & 0.52 \\
\hline Negative Affect 10 & & $0.33^{*}$ & & 0.43 \\
\hline Eigen values & 5.91 & 3.58 & 3.24 & \\
\hline$\%$ of Variance & 20.76 & 14.34 & 12.80 & 47.91 \\
\hline
\end{tabular}

Source: own work

Besides this, thereliabilities of the scales after being subjected to PCA are discussed further. The over-all Cronbach-alpha reliability for the QWL scale has been reported to be 0.89 . For the 7 dimensions, reliability isas follows: SMS (0.77), FWS (0.76), SAB (0.76), RWC (0.73), IRW(0.78), CDJS(0.79), JSCA(0.79). For the Trust scale, the over-all Cronbach-alpha reliability has been reported to be (0.85). The reliability of 2 dimensions of trust are as follows: ABT (0.75) and CBT (0.85) respectively. For the SWB Scale, the over-all Cronbach-alpha reliability has been reported to be 0.67 . The reliability dimensions are as follows: LS (0.71), PA (0.78) and NA (0.76), respectively.

\section{Results and Discussion}

The present study investigates the influence of QWL on Trust. In addition to this, the study investigates the influence of OWL on SWB. Furthermore, the construct 'Trust' as a missing link between QWL and SWB. 


\subsection{Stepwise Regression Analysis}

3.1.1 Quality of work life will significantly predict trust: Stepwise regression analysis was employed to verify $\mathrm{H} 1$. Table 1 represents the prediction of trust as a dependent variable and QWL as an independent variable. The seven dimensions of OWL have been putinto the regression equation, and results show that SMS has predicted affect-based trust (ABT) with the calculated $R$ as $0.63(F=228.65 * *, p>0.01, \beta=0.61$, $\left.R^{2}=0.39\right)$; while SMS and IRW were jointly predicted with the multiple $R$ as $0.66(F=$ $\left.134.35 * *, p<0.01, \beta=0.21, R^{2}=0.44\right)$; SMS, IRW and SAB with multiple $R$ as $0.67(F=$ $\left.95.23 * *, p<0.01, \beta=0.17, R^{2}=0.45\right)$ and $45 \%$ of variance in the prediction of affect-based trust (ABT). As a whole, the strongest predictors of affect-based trust were found to be SMS with the beta value as 0.48. In a similar manner, cognition-based trust (CBT) has been predicted by CDJ with the $R$ value as 0.55 ( $F=150.85 * *, p>0.01, \beta$ $\left.=0.55, R^{2}=0.30\right)$; CDJ and RWC were jointly predicted with the multiple $R$ as $0.64(F=$ 122.48**, $\left.p<0.01, \beta=0.35, R^{2}=0.41\right) ; C D J, R W C$ and $F W S$ with multiple $R$ as $0.67(F=$ 98.05**, $\left.p<0.01, \beta=0.28, R^{2}=0.46\right) ; C D J, R W C, F W S$ and SMS with multiple $R$ as 0.69 $\left(F=79.63 * *, p<0.01, \beta=0.19, R^{2}=0.48\right) ; C D J, R W C, F W S, S M S$ and $S A B$ with multiple $R$ as $0.69\left(F=65.56 * *, p<0.01, \beta=0.12, R^{2}=0.48\right)$; RWC, FWS, SMS and SAB with multiple $R$ as $0.70\left(F=80.40 * *, p<0.01, \beta=0.17, R^{2}=0.49\right)$; with a calculated variance of $49 \%$ in the prediction of cognition-based trust (CBT). As a whole, the strongest predictors of CBT with the reported $\beta$ value as 0.35 wereRWC. On the basis of the interpretation of the resultswith in Table 4, SMS and RWC were considered as the potential predictors of trust.

Table 4. Stepwise Regression Analysis for the Influence of Trust

\begin{tabular}{lccccccc}
\hline \multicolumn{1}{c}{ Variables } & $\mathbf{R}$ & $\mathbf{R}^{\mathbf{2}}$ & $\boldsymbol{\Delta} \mathbf{R}^{\mathbf{2}}$ & S.E.m & F-value & df & Beta \\
\hline D.V: ABT SMS & 0.61 & 0.39 & 0.39 & 4.41 & $228.65^{* \star}$ & 1,348 & 0.61 \\
\hline SMS, IRW & 0.66 & 0.44 & 0.43 & 4.26 & $134.35^{* *}$ & 1,347 & $0.58,0.21$ \\
\hline SMS, IRW,SAB & 0.67 & 0.45 & 0.44 & 4.21 & $95.23^{* *}$ & 1,346 & $0.48,0.18,0.17$ \\
\hline D.V: CBT CDJ & 0.55 & 0.30 & 0.30 & 4.86 & $150.85^{* \star}$ & 1,348 & 0.55 \\
\hline CDJ, RWC & 0.64 & 0.41 & 0.41 & 4.37 & $122.48^{* *}$ & 1,347 & $0.45,0.35$ \\
\hline CDJ, RWC,FWS & 0.67 & 0.46 & 0.46 & 4.21 & $98.05^{* *}$ & 1,346 & $0.26,0.37,0.28$ \\
\hline CDJ, RWC,FWS, SMS & 0.69 & 0.48 & 0.47 & 4.13 & $79.63^{* \star}$ & 1,345 & $0.17,0.35,0.24,0.19$ \\
\hline CDJ, RWC,FWS, SMS,SAB & 0.69 & 0.48 & 0.48 & 4.12 & $65.56^{* *}$ & 1,344 & $0.10,0.34,0.23,0.16,0.12$ \\
\hline RWC,FWS, SMS,SAB & 0.70 & 0.49 & 0.48 & 4.13 & $80.40^{* *}$ & 1,343 & $0.35,0.26,0.19,0.17$ \\
\hline
\end{tabular}

Note: ** significant at $p<0.01$.

Source: own work 
3.1.2: Quality of work life will influence Subjective well-being: Following the same procedure and enteringseven predictors, the seven dimensions of QWL,these predictors jointly contributed in the prediction of dimensions of subjective well-being. The results (influence of $\mathrm{OWL}$ on SWB) mentioned in Table 2, reported that out of all the dimensions of quality of work life, SAB has influenced life satisfaction(LS) with the calculated $R$ as $0.45\left(F=89.29 * *, p>0.01, \beta=0.45, R^{2}=0.20\right)$; $S A B$ and $F W S$ jointly with multiple $R$ as $0.50\left(F=57.99 * *, p<0.01, \beta=0.24, R^{2}=0.25\right)$; $S A B, F W S$ and RWC with multiple $R$ as $0.53\left(F=46.58 * *, p<0.01, \beta=0.20, R^{2}=0.28\right)$ and jointly accounted for $28 \%$ of variance in the influence of life satisfaction (LS). Overall results show that SAB is the strongest predictor of life satisfaction (LS) with the $\beta$ value as 0.39 . Positive affect has been predicted by SMS with the calculated $R$ as 0.35 ( $F=47.61 * *$, $\left.p>0.01, \beta=0.35, R^{2}=0.12\right)$; SMS and CDJ jointly with multiple $R$ as $0.37(F=27.67 * *$, $\left.p<0.01, \beta=0.19, R^{2}=0.13\right)$; SMS, CDJ and FWS with multiple $R$ as $0.39(F=21.72 * *$, $\left.p<0.01, \beta=0.18, R^{2}=0.15\right)$; SMS, CDJ, FWS, and SAB with multiple $R$ as 0.41 ( $F=17.56 * *$, $p<0.01, \beta=0.14, R^{2}=0.16$ ) and jointly accounted for $16 \%$ of variance in the influence of positive affect. Overall, SMS and CDJ were the strongest influencers of positive affect with the calculated $\mathrm{R}$ as 0.30 respectively.

Negative affect has been predicted by FWS with the calculated $R$ as $0.42\left(F=76.37 * *, p>0.01, \beta=-0.42, R^{2}=0.18\right) ; F W S$ and $S M S$ jointly with multiple $R$ as $0.44\left(F=41.57 * *, p<0.01, \beta=-0.13, R^{2}=0.19\right) ; F W S, S M S$, and JSCA with multiple $R$ as $0.48\left(F=34.03 * *, p<0.01, \beta=-0.24, R^{2}=0.22\right)$ and jointly predicted for $22 \%$ of variance in the prediction of Negative Affect. Overall, FWS is the strongest influencer of negative affect with the calculated Beta value as -0.39 . Further, from the interpretation of the results of Table 5, SAB, SMS, CDJ and FWS were found to be the potential influencers of SWB.

Table 5. Stepwise Regression Analysis for the Prediction of Subjective Well-Being

\begin{tabular}{lccccccc}
\hline \multicolumn{1}{c}{ Variables } & $\mathbf{R}$ & $\mathbf{R}^{\mathbf{2}}$ & $\boldsymbol{\Delta} \mathbf{R}^{\mathbf{2}}$ & S.E.m & F-value & df & Beta \\
\hline D.V: LS SAB & 0.45 & 0.20 & 0.20 & 4.49 & $89.29^{* *}$ & 1,348 & 0.45 \\
\hline SAB, FWS & 0.50 & 0.25 & 0.25 & 4.37 & $57.99^{* *}$ & 1,347 & $0.32,0.24$ \\
\hline SAB, FWS, RWC & 0.53 & 0.28 & 0.28 & 4.27 & $46.58^{* *}$ & 1,346 & $0.39,0.23,0.20$ \\
\hline D.V: PA SMS & 0.35 & 0.12 & 0.11 & 5.40 & $47.61^{* *}$ & 1,348 & 0.35 \\
\hline SMS, CDJ & 0.37 & 0.13 & 0.13 & 5.39 & $27.67^{* *}$ & 1,347 & $0.21,0.19$ \\
\hline SMS, CDJ , FWS & 0.39 & 0.15 & 0.15 & 5.29 & $21.72^{* *}$ & 1,346 & $0.25,0.27,0.18$ \\
\hline SMS, CDJ, FWS, SAB & 0.41 & 0.16 & 0.16 & 5.27 & $17.56^{* *}$ & 1,345 & $0.30,0.30,0.17,0.14$ \\
\hline
\end{tabular}


(viene)

\begin{tabular}{lccccccc}
\hline \multicolumn{1}{c}{ Variables } & $\mathbf{R}$ & $\mathbf{R}^{\mathbf{2}}$ & $\boldsymbol{\Delta R}^{\mathbf{2}}$ & S.E.m & F-value & df & Beta \\
\hline D.V: NA FWS & 0.42 & 0.18 & 0.18 & 4.26 & $76.37^{* *}$ & 1,348 & -0.42 \\
\hline FWS, SMS & 0.44 & 0.19 & 0.19 & 4.24 & $41.57^{* *}$ & 1,347 & $-0.34,-0.13$ \\
\hline FWS, SMS, JSCA & 0.48 & 0.22 & 0.22 & 4.15 & $34.03^{* *}$ & 1,346 & $-0.39,-0.27,-0.24$ \\
\hline
\end{tabular}

Note: ** significant at $p<0.01$ level

Source: own work

3.2: Mediation Analysis: To examine the hypothesis that trust will mediate the association between $\mathrm{QWL}$ and SWB,a bootstrapping approach was used with the help of an $\mathrm{AMOS}^{\circledR}$ 20. Figure 1 represents the direct path (c) of OWL and SWB, while the mediated path between QWL and SWB via Trust ( $\left.c^{\prime}\right)$. Results exhibited in Table 6 indicate that the indirect effect of $\mathrm{QWL}$ on SWB which is represented as $(a \times b)$ through trust was 0.100 (SE 0.044, Cl at 95\% significance level is $0.011-0.181$ ) and is significant at $p<0.005$. The results justified that the influence of $Q W L$ on SWB is decreased when trust mediated the path but still remained significant;thisshows the presence of partial mediation. It is sufficient to recommend that the causal path between QWL to SWB was partially mediated by trust. Thus, $\mathrm{H} 3$ of this research is partially supported.

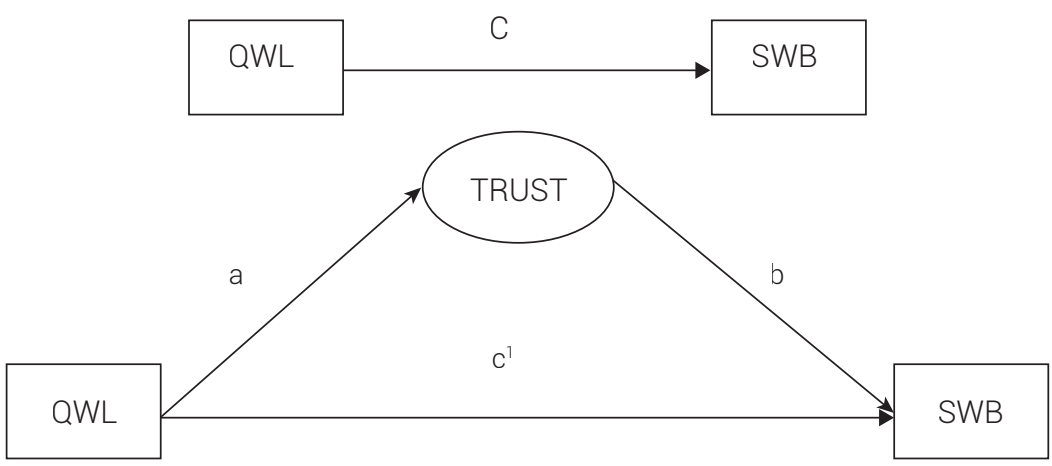

Figure 1. Mediation path of QWL and SWB via Trust Source: own work 
Table 6. Mediation Results of QWL on SWB via Trust

\begin{tabular}{|c|c|c|c|c|}
\hline Paths & Std Coefficient & SE & $\begin{array}{c}\text { CI for Indirect } \\
\text { Effect }\end{array}$ & $\mathbf{P}$ \\
\hline Direct Effect QWL -SWB $\left\{c^{i}\right\}$ & 0.43 & 0.061 & \multirow{5}{*}{$\begin{array}{l}\text { Lower Bound }=0.011 \\
\text { Upper Bound }=0.181\end{array}$} & *** \\
\hline Direct effect QWL-Trust $\{a\}$ & 0.63 & 0.026 & & *** \\
\hline Direct Effect Trust -SWB $\{b\}$ & 0.16 & 0.071 & & *** \\
\hline Total Effect QWL-SWB $\{c\}$ & 0.53 & & & *** \\
\hline Indirect Effect QWL-SWB $\{a \times b\}$ & 0.100 & 0.044 & & *** \\
\hline
\end{tabular}

Source: own work

Further, Table 7 shows the findings of regression analysis. All the study variables are related to each other significantly $(p<0.01)$. QWL is found to be a significant predictor of SWB (0.23). Similarly, QWL is found to be significant predictor of trust (0.27). Also, trust is found to be significantly in predicting subjective well-being (0.43). Thus, all the preconditions for mediation as suggested were met. For this study, quality of work life is an independent variable, subjective well-being acts as a dependent variable and the mediating variable is trust. On the basis of Table 7, it can be deduced that the conditions for mediation are met as the relationship of OWL and SWB when controloftrust was reduced to 0.43 from 0.23 , however, it still remained significant $(p<0.01)$. Thus, the results support partial mediation and hypothesis $\mathrm{H} 3$ is also partially supported.

Table 7. Regression Analysis to test the mediating effect

\begin{tabular}{lccccc}
\hline \multicolumn{1}{c}{ Variable } & B & t-value & F-value & Df & $\mathbf{R}^{\mathbf{2}}$ \\
\hline Analysis 1: SWB on QWL & 0.23 & $11.67^{*}$ & $136.10^{*}$ & 1,348 & 0.281 \\
\hline Analysis 2: Trust on QWL & 0.27 & $15.08^{*}$ & $227.36^{*}$ & 1,348 & 0.395 \\
\hline Analysis 3: & & & & & \\
\cline { 1 - 3 } Step 1: SWB on Trust & 0.16 & $2.76^{*}$ & \multirow{2}{*}{73.14} & 2,347 & 0.297 \\
\cline { 1 - 3 } Step 2: SWB on QWL & 0.43 & $7.43^{*}$ & & & \\
\hline
\end{tabular}

Source: own work

3.3 Empirical support for the hypotheses: The present research has been proposed to investigate the influence of $\mathrm{OWL}$ on trust and subjective well-being of employees also to see the mediating effect of trust on QWL and SWB among IT employees. Thepresent findings have revealed that positive exposure and satisfaction at the workplace definitely enhance the level of trust and subjective well-being of IT employees by transforming them into fully functional peoplein all domains of life. 
3.3.1 Prediction of Trust on the basis of Quality of Work Life: The findings reveal that the over-all QWL has proved to be a significant influence on trust. Table 4 indicates that affect-based trust has been predicted by support from managers and supervisors, followed by involvement,responsibility at work, salary and additional benefits. The results reveal that support, healthy interaction and participation elicit a sense of reciprocation within IT employees [11] and can achieve new parameters in the professional life. The findings suggest that support, adequate benefits, involvement, responsibility and guidance at workplace also lead to supportive behavior, interaction, and a sense of personal and professional security. Furthermore, cognition-based trust has been predicted by relationships with work colleagues followed by low stress and the support of supervisors, and salary and additional benefits. The results reveal that employees who believed that their colleagues are reliable, and are willing to act on the basis of their co-worker's words, actions, and decisions, feeling more optimistic and enthusiastic about the organizational support [12]. On an overall basis, support from seniors and authorities, experiencing low stress, having job security, harmony at the workplace, healthy communication, salary, and active participation in making decisions enhances the level of trust among employees. It can be stated that the overall quality of work life leads an employee to feel competent, consistent, discreet, fair, and integral with a sense of benevolence, faith, belief and reciprocation for enhancing the perception of trust among organizations.

\subsubsection{Prediction of Subjective Well-being on the basis of Quality of Work Life}

Table 5 shows the prediction of subjective well-being of employees on the basis of quality of work life. The results reveal that the overall quality of work life has proved to be a significant influence on the subjective well-being of employees. Table 5 indicates that life satisfaction has been predicted by salary and additional benefits followed by low stress and relationships with work colleagues. The results reveal that economic factors like income and other additional benefits are vital to the employee's performance and the whole organization. It can also be stated that reduced work pressure and stress lead to employees enjoyingwork and developing positive relations and interactions with colleagues and seniors, and when carried to other spheres of life, establish mutual respect and trust with others (family members, friends and others) [13]. In addition, having harmonious relationships at the workplace that then spill over into the personal domain, promotes healthy and happy vibes with reduced stress, hostility, sadness and antagonism [14]. It reduces negative emotions and establishes 
healthy relationships which generate a positive environment among friends, family and community, which in turn helps in welcoming a social environment withindividual experiences of societal and interpersonal well-being and life satisfaction. Therefore, it can be stated that workplace satisfaction and happiness when carried over to other domains of life, generates positivism, self-initiation, self-direction [15] and overall life satisfaction [16]. Similarly, positive affect has been predicted by support from managers and supervisors followed by communication, decision making and job security and then low stress, salary and additional benefits. The results reveal that support, healthy interaction, communication, participation and adequate benefits elicit a sense of positive affect within IT employees and can achieve new parameters in professional life such as management and leadership;essential to the functioning of organizations within every society [17]. Furthermore, negative affect has been predicted by low stress followed by job satisfaction, challenge and autonomy and support of a supervisor. The results reveal that experiencing stress, workload and low empowerment and performing less challenging tasks have a deterimental influence with the displacement of aggression, frustration in personal relationships, poor communication and marital adjustment [18]which leads to negative emotions in one's life. The results reveal that FWS negatively predicted NA which means that reduced stress helps in reducing negativity in both personal and professional domains of an individual life.

\subsubsection{Quality of Work Life and Subjective Well-being: Missing Link of Trust:}

$\mathrm{H} 3$ of the study presumed that trust acts as a mediator between quality of work life and subjective well-being. The results substantiate the fact that QWL is also related to trust. Scholars often define QWL as interpersonal, cooperative, open, informal and evolutionary. On similar lines, work environment laced with QWL is denoted as ethical and productive because it establishes an environment of trust and faith in their employees. Becerra and Gupta [19] viewed that positive mood stating that a leader should demonstrate his/her positive behavioral intentions for the followers. In this way, the emotional bond between the leader and follower strengthens which increases the probability of the development oftrust between them. Chawla and Kelloway [20] found that trust can be generated in organizations when communication, participation, and job security were incorporated into the system. In addition, social capital was also associated with the norms of trust and SWB [21], [22],[23] and[24]. Hence, it is obvious to proclaim that trust mediates the relationship of quality of work life and subjective well-being and was proved to bethe missing link. 


\section{Conclusion}

The present results of the study help toenlighten the role of various dimensions of QWL in predicting trust and the subjective well-being of employees. It has been identified that a trusted employee is a valuable asset available to an organization. The present study has focused on the Indian IT employees and the findings have indicated that experiencing optimum quality of work life plays a significant function in determining and increasing subjective well-being of employees. In addition, the findings suggest that understanding of psychological principles and premises of human behavior is crucial for the success of organizational plans and policies which have a spilled over effect on the family life of an employee. Thus, it is essential to identify and develop ways to facilitate the well-being among employees and the organizations. This further creates a feeling of happiness which indicates that 'happy and satisfied workers produce more' [25].

\section{REFERENCES}

[1] Agarwal, Shivani, P. Garg, and R. Rastogi, "Testing the reciprocal relationship between quality of work life and subjective well-being: a path analysis model," International Journal of Project Organisation and Management, vol. 11, no. 2, pp. 140-153, 2019. [Online]. doi: 10.1504/ IJPOM.2019.100576

[2] B. Ballou, and N.H. Godwin, "Quality of work life,"Strategic Finance, October, pp. 41-45, 2007.

[3] T. Kotzé, "Quality of work life: What managers need to know,"Management Today, vol. 20, no.6, pp. 38-41, 2004

[4] K. Newton, "Social trust: Individual and cross-national approaches,"Portuguese Journal of Social Science, vol. 3, pp.15-35, 2004

[5] J. W. Newstrom andK. Davis, “Organizational Behavior at Work," New York: McGraw Hill Book Company, 2005

[6] A. S. McDonald and National Foundation for Educational Research in England and Wales, "Quality of working life: User's guide," Windsor: NFER-Nelson,2007.

[7] D. M.Rousseau, S. B.Sitkin, R. S. Burt, and C. Camerer, "Not so different after all: A cross-discipline view of trust,"Academy of Management Review, vol.23,no. 3, pp. 393-404, 1998. [Online]. doi:https://doi.org/10.5465/amr.1998.926617 
[8] D. J.McAllister, "Affect- and cognition-based trust as foundations for interpersonal cooperation in organizations,"Academy of Management Journal, vol. 38, pp. 24-59, 1995. [Online]. doi:https://www.jstor.org/stable/256727

[9] E. Diener, "Subjective well-being,"Psychological Bulletin,vol.95, pp. 542-575, 1984. [Online] doi:http://dx.doi.org/10.1037/0033-2909.95.3.542

[10] D. Watson, L. A. Clark and A. Tellegen, "Development and validation of brief measures of positive and negative affect: The PANAS scales," Journal of Personality and Social Psychology, vol. 54, no. 6, pp. 1063-1070, 1988. [Online]. doi:http://dx.doi.org/10.1037/0022-3514.54.6.1063

[11] Y. P. Sahay, and M. Gupta, "Role of organization structure in innovation in the bulk-drug industry,"Indian Journal of Industrial relations, vol. 45, no. 3,pp. 450-464, 2011.[Online]. doi:https://www.jstor.org/stable/41149462

[12] J. Ferres, J. Connell and A. Travaglione, "Co-worker trust as a social catalyst for constructive employee attitudes,"Journal of Management Psychology, vol. 19, no. 6, pp. 608-622, 2004. [Online]. doi:https://doi.org/10.1108/02683940410551516

[13] R. F. Baumeister andM. R. Leary,"The need to belong: Desire for interpersonal attachments as a fundamental human motivation,”Psychological Bulletin,vol. 117, no. 3, pp. 497-529, 1995. [Online] doi: 10.1037\%2F0033-2909.117.3.497

[14] K. Daniels, "Measures of five aspects of affective well-being at Work," HumanRelations, vol. 53, pp. 275-294, 2000. [Online]. doi:10.1177/a010564

[15] T. T. Serey, "Choosing a Robust Quality of Work Life,"Business Forum, vol. 27, pp. 7-10, (2006).

[16] J. L. Katrina, J. Andrew, J. Noblet and J. J. Rodwell,“Promoting employee well-being: The relevance of work characteristics and organizational justice," HealthPromotion International, vol. 24, pp. 223-233, 2009.[Online]. doi:10.1093/heapro/dap025

[17] Kalliny, Morris., Ulas, Ograk., \& Saran, A.,"Management Styles and Commitment: A CrossCultural Study",The Journal of Global Business Management, vol. 3, no.1, pp. 1-5, 2007

[18] H. A. Hashmi, M. Khurshid and I. Hassan, "Marital adjustment, stress and depression among working and non-working married women,"Internet Journal of Medical Update,vol. 2, pp. 19-26, 2007. 
[19] M. Becerra and A. K. Gupta, "Perceived trustworthiness within the organization: The moderating impact of communication frequency on trustor and trustee effects," Organization Science, vol. 14, no. 1, pp. 32-44,2003. [Online]. doi: http://dx.doi.org/10.1287/orsc.14.1.32.12815.

[20] A.Chawla and E. K. Kelloway, "Predicting openness and commitment to change,"Leadership \& Organization Development Journal, vol. 25, no.5/6, pp. 485-498, 2004. [Online] doi: https:// doi.org/10.1108/01437730410556734

[21] R.D.Putnam, Bowling Alone: The Collapse and Revival of American Community, New York, Simon \& Schuster, 2000.

[22] J.S.Coleman, "Social capital in the creation of human capital,"The American Journal of Sociology, vol. 94, no.S95,1988. [Online] doi:http://www.jstor.org/stable/2780243

[23] C. Kroll, "Different things make different people happy: examining social capital and subjective well-being by gender and parental status",Social Indicator Research,vol. 104, pp. 157-177, 2011. [Online]. doi:https://doi.org/10.1093/heapro/dap025

[24] A. Kulig, H. Kolfoort and R. Hoekstra, "The case of the hybrid capital approach for the measurement of the welfare and sustainability,"Ecol. Indic., vol. 10, pp. 118-128, 2010. [Online]. doi:https://doi.org/10.1007/s11205-010-9733-1

[25] T. A. Wright and R. Cropanzano, "The role of psychological well-being in job performance: A fresh look at an age-old quest,"'Organizational Dynamics, vol. 33, no. 4,pp. 338-351, 2004. [Online]. doi:http://10.1016/j.orgdyn.2004.09.002 